\title{
Angiogenesis in pterygium: study of microvessel density, vascular endothelial growth factor, and thrombospondin-1
}

M Aspiotis'1, E Tsanou², S Gorezis' ${ }^{1}$ E Ioachim², A Skyrlas², M Stefaniotou' and V Malamou-Mitsi

\begin{abstract}
Purpose This retrospective study aims to elucidate the role of angiogenesis in the pathogenesis of pterygium. We evaluated microvessel density (MVD), and expression of vascular endothelial growth factor (VEGF) and thrombospondin-1 (TSP-1).
\end{abstract}

Methods Fifty-two surgically excised pterygia and seven normal conjunctivae were immunohistochemically studied applying the streptavidin-biotin method in paraffinembedded tissue sections. Monoclonal antibodies were targeted against CD31, VEGF, and TSP-1 proteins.

Results Pterygium presented with statistically significant higher average count of microvessels compared to normal conjunctivae (17.97 \pm 8.5 vs $5.72 \pm 5$ per high power field, $P=0.001)$. In $24 / 52(46.2 \%)$ cases of pterygium, high expression levels for VEGF were demonstrated, whereas the mean percentage of VEGF-positive epithelial cells was $58.03 \%$. Furthermore, normal conjunctival presented statistically significant higher expression levels for VEGF in epithelial cells (83.14 \pm 36.08 vs $58.03 \pm 31.23 \%, P=0.007)$. On the contrary, the presence of VEGF immunoreactivity in vascular endothelial and stromal cells was significantly higher in pterygium tissues $(P<0.0001)$. Stromal staining for TSP-1 was detected in only 29/52 (55.8\%) of the cases and no correlation with normal conjunctivae was found. Finally, statistically significant positive correlation between MVD values and stromal VEGF expression was found $(P=0.049)$. Conclusion The angiogenesis-related factors that were studied proved to be highly expressed in pterygium tissue. On the contrary, TSP expression level was low, allowing inducers of angiogenesis to act uninhibited. This phenomenon could provide the pathogenic basis of pterygium formation. Eye (2007) 21, 1095-1101; doi:10.1038/sj.eye.6702495; published online 23 June 2006

Keywords: pterygium; angiogenesis; microvessel density; VEGF; thrombospondin

\section{Introduction}

Pterygia are surface ocular lesions that begin growing from limbal epithelium that invades the cornea centripetally followed by conjunctival epithelium. ${ }^{1,2}$ Histologically, actively growing pterygia exhibit both degenerative and hyperplastic changes as well as proliferative and inflammatory disorders. ${ }^{3,4}$ They consist of an overlying conjunctival epithelium, which can appear normal or mildly hyperplastic. The underlying fibrovascular tissue usually presents a chronic inflammatory cellular infiltrate and rich vasculature. ${ }^{4}$ The pathogenesis of pterygia is still controversial, although epidemiological studies have firmly established that ultraviolet radiation is an aetiologic agent for pterygia. ${ }^{5}$ In addition, many fibroangiogenic growth factors have been implicated in pterygium pathogenesis, such as tumour necrosis factor- $\alpha$ (TNF- $\alpha$ ), basic fibroblast growth factor (bFGF), platelet-derived growth factor (PDGF), and transforming growth factor- $\beta$ (TGF- $\beta$ ). Immunoreactivity for these growth factors was located in the epithelial cells, endothelial cells of vessels, basement membranes of vessels and epithelium, fibroblasts, and infiltrating inflammatory cells in the pterygium. ${ }^{6}$ Conjunctival epithelial cells are capable of producing proinflammatory
${ }^{1}$ Department of Ophthalmology, University of Ioannina, loannina, Epirus, Greece

${ }^{2}$ Department of PathologyCytology, University of Ioannina, loannina, Epirus, Greece

Correspondence: M Aspiotis,

Department of

Ophthalmology,

University of Ioannina, loannina,

Epirus 45110,

Greece

Tel: + 302651077747 ;

Fax: + 302651032266

E-mail: gorezis@hotmail.com

Received: 5 December 2005 Accepted in revised form: 25 May 2006

Published online: 23 June 2006 
cytokines, such as TNF- $\alpha$ and IL- $1 \beta$, which in turn stimulate Tenon's capsule fibroblastic proliferation, in tissue cultures. ${ }^{7}$ Angiogenesis is defined as the formation of new blood vessels from pre-existing vasculature and underlies a large number of physiological processes, ${ }^{8}$ such as growth and differentiation, ovulation, would healing, and abnormal conditions such as neoplasia and eye diseases, which cause severe loss of vision. ${ }^{9}$ The process of vascularization involves the activation of cell-derived angiogenic factors as well as the appropriate synthesis of extracellular matrix components necessary for anchorage of migrating endothelium. Among others, vascular endothelial growth factor (VEGF) presents of extremely interest, as its expression is induced by hypoxia.

The process of angiogenesis is governed by a complex balance of positive and negative regulatory factors.

One of the most potent and specific angiogenic factors is VEGF, also known as vascular permeability factor and vasculotropin. ${ }^{10}$ VEGF is a heparin-binding glycoprotein that has several important effects on vascular endothelial cells. This growth factor may produce in response to environment stimuli, mainly hypoxia, certain cytokines, and estradiol. ${ }^{11-13}$ Currently, VEGF is considered to be the most selective mitogen for endothelial cells, ${ }^{14}$ increases vascular permeability, ${ }^{15}$ induces alterations in ion flow, cell proliferation, ${ }^{16}$ and migration and release of proteinases. $^{17}$

In counterbalance, thrombospondin-1 (TSP-1) is a multifunctional platelet and extracellular matrix protein. ${ }^{18}$ TSP-1 is involved in diverse processes such as regulation of cell growth, cell motility, inflammation, and wound healing. It modulates endothelial cell motility, growth, apoptosis, and adhesion to cancer cells, thus it is considered to be an inhibitor of angiogenesis. ${ }^{19}$ In the present study, we assessed the interrelationship of microvessel density (MVD), assessed by CD31, with the expression of angiogenic factor VEGF and the endogenous inhibitor of angiogenesis TSP-1 in patients with pterygium and bulbar conjunctival, in an effort to elucidate the role of certain factors related to angiogenesis in the pathogenesis of pterygium. We emphasize on the fact that it is the first study that investigates the presence of TSP-1 in pterygium.

\section{Materials and methods}

\section{Patients and study design}

The study group included 52 cases of surgically excised pterygium, half of them nasal and temporal (51 were primary and one was recurrent). All the patients have been consented and the investigation has been appropriated by Hospital Ethic Committee. Twenty-two patients were male and 30 female, while the age range was 59-82 years. During excision, except from local, topical anaesthesia, no other chemical or pharmaceutical factor was administered. Seven nasal epibulbar conjunctivae segments, excised during cataract surgery near the limbus, were used as control tissue, after informed consent was obtained.

All sections were sent to the Pathology Department, were stained with hematoxylin-eosin and according to their main cellular component were categorized as vascular $(30.8 \%)$, fibrous (25\%), and mixed $(44.2 \%)$.

\section{Immunohistochemistry}

Immunostaining was performed on formalin-fixed, paraffin-embedded tissue sections by the labelled streptavidin-avidin-biotin method. In brief, tissue sections of pterygium and normal conjunctiva, $2-4 \mu \mathrm{m}$ thick, were deparaffinized in xylene and dehydrated. They were immersed in citrate buffer $(0.1 \mathrm{ml}, \mathrm{pH} 0.6)$ and subjected to microwave irradiation twice for $15 \mathrm{~min}$. Subsequently, all sections were treated for $30 \mathrm{~min}$ with $0.3 \%$ hydrogen peroxide in methanol to quench endogenous peroxidase activity. Monoclonal antibodies directed against CD31 (DAKO, dilution 1/50), VEGF (Neomarkers, dilution 1/50), and TSP (Menarin, dilution of $1: 30)$ were applied. Mouse primary monoclonal antibodies were incubated on tissue sections overnight at $4^{\circ} \mathrm{C}$, and then extensively washed in $0.05 \mathrm{M}$ Tris-buffered saline ( $\mathrm{pH} 7.6$ ), before the addition of biotinylated secondary antibody (goat anti-mouse). Sections were again washed and incubated with horseradish peroxidase-conjugated streptavidin (DAKO, $1: 100)$ and developed the chromogen with immersion of the slides in a diaminobezidine $-\mathrm{H}_{2} \mathrm{O}_{2}$ substrate for $5 \mathrm{~min}$. Positive control slides were included in all cases, whereas sections subjected to the whole procedure, except incubation with the primary antibody, were used as 'negative' controls. All dilutions were made in TBS-1\% BSA solution and were followed by overnight incubation.

The staining assessment of the three parameters was made by two experienced observers in light microscope.

MVD was evaluated by CD31 staining of vascular endothelial cells. Any stained endothelial cells or endothelial cell clusters clearly separated from connective tissue elements were considered as a single microvessel. A lumen was not required to identify a vessel. Large vessels with thick muscular walls were excluded from the count. Vessels within muscular walls or lumens larger than approximately eight red blood cells were also excluded from the count. Vessels had to be separated clearly from each other to be counted. No counts were performed in areas of necrosis or inflammation. In each sample, three areas of most 


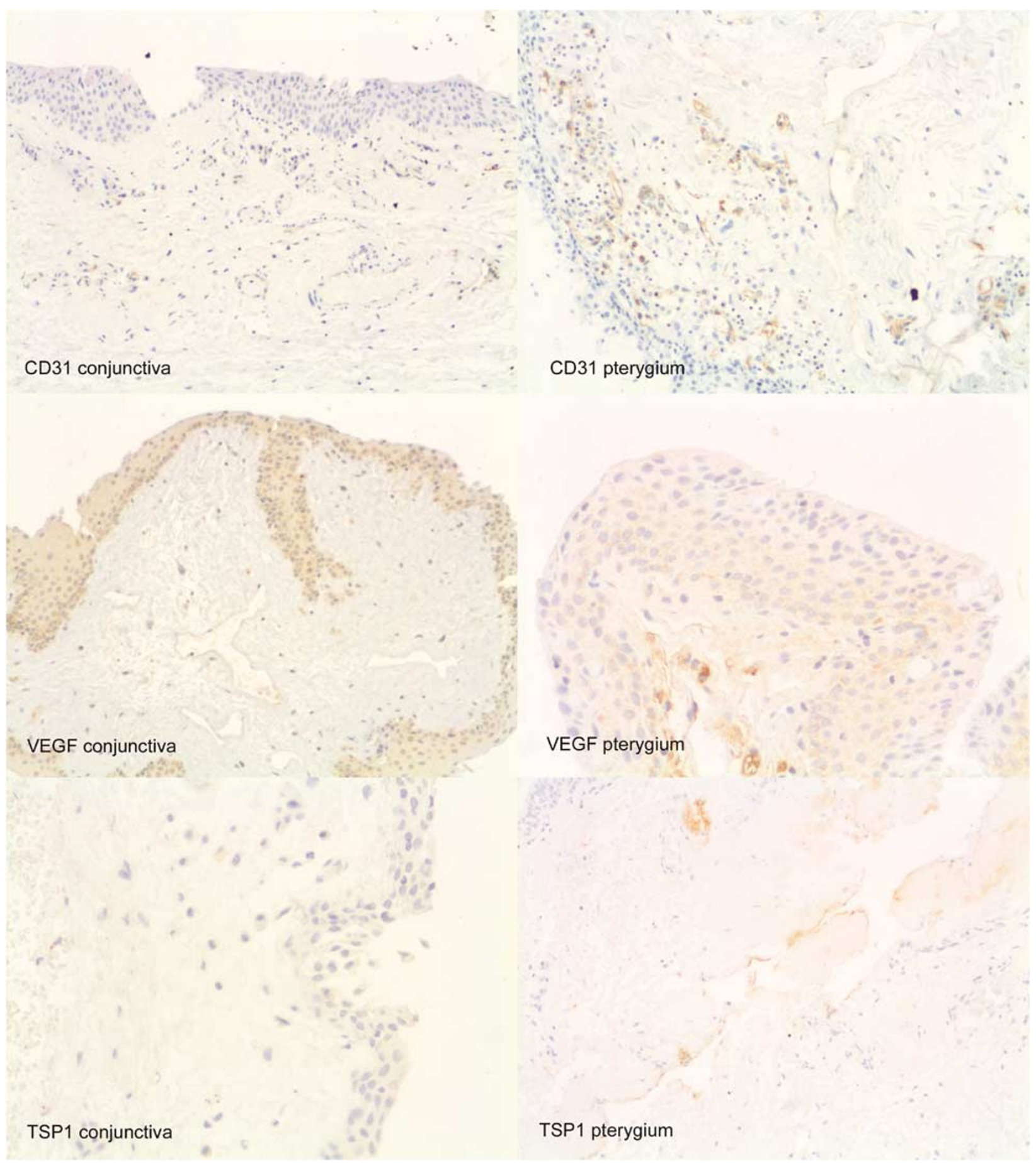

Figure 1 Staining patterns of VEGF and TSP-1 in pterygium tissues (a), VEGF mild, (b) VEGF intermediate, (c) VEGF strong staining intensity, and (d) absence of staining, (e) mild, focal staining, and (f) intense, diffuse staining for TSP-1.

prominent vascular density were identified at a $\times 40$ power field $\left(0.65 \mathrm{~mm}^{2}\right)$ and the average number of the three counts was recorded.

Immunoreactivity for VEGF presented in endothelial, stromal, and epithelial cells was only assessed in epithelial cells. To evaluate the expression of VEGF protein in epithelial cells, we established a combined score corresponding to the sum of both (a) staining intensity $(0=$ negative, $1=$ weak, $2=$ intermediate, $3=$ strong staining) and percentile quadrants of positive cells $(0=0 \%, 1=1-25 \%, 2=26-50 \%, 3=>50 \%)$. The sum reached a maximum score of 6 . Scores 1 and 2 were 
regarded as weak, 3 as intermediate, and 4-6 as strongly positive. For the estimation in stromal and endothelial cells, we used a semiquantitative score with a three-scale system: 0 , no expression; + , focal expression; ++ , diffuse expression.

For TSP-1, only extracellular matrix immunoreactivity was assessed. The results were graded according to the extent and the intensity of immunoreaction. Using a semiquantitative method, the tissue sections were classified as negative, +1 : mild, focal; +2 : strong, diffuse reactivity. The different staining patterns of VEGF and TSP-1 in pterygium tissues are demonstrated in Figure 1.

\section{Statistical analysis}

The program SPSS for Windows Release 10.0 was used for statistical analysis. Pearson's and Spearman's correlation coefficients were used for the assessment of correlation between continuous variables. The Mann-Whitney $U$-test was used to assess the correlation between different protein patterns. The results were considered as statistically significant when $P<0.05$.

\section{Results}

The mean value of MVD in pterygium was 17.97 per high power field. Intense angiogenic activity was observed particularly at the subepithelial area (Figure 2).
Pterygium tissues were more vascularized than normal conjunctivae, that presented mean MVD value of 5.72 per high power field, and a statistically significant correlation was demonstrated $(P=0.001)$.

Intense immunoreactivity of epithelial, vascular endothelial, and many fibroblastic and inflammatory stromal cells was observed for VEGF. The staining reaction was diffuse, granular, cytoplasmic, with intensification at the superficial layers of the epithelium (Figure 2). The mean percentage of VEGF-positive epithelial cells was $58.03 \%$. Specifically, 24/52 (46.2\%) cases presented high combined score (5-6) concerning VEGF (Table 1). A statistically significant difference with normal conjunctivae was demonstrated $(P=0.007)$, which presented extremely high expression levels for VEGF in epithelial component (83.14\%). In normal conjunctival tissues, no VEGF immunoreactivity was observed in endothelial or stromal cells, in contrast to the

Table 1 Epithelial immunoreactivity of VEGF in pterygium

\begin{tabular}{lcc}
\hline & No cases & Percentage (\%) \\
\hline Combined score & & \\
$1-2$ & 12 & 23.1 \\
$3-4$ & 16 & 30.8 \\
$5-6$ & 24 & 46.2 \\
Total & 52 & 100 \\
\hline
\end{tabular}

VEGF: vascular endothelial growth factor.

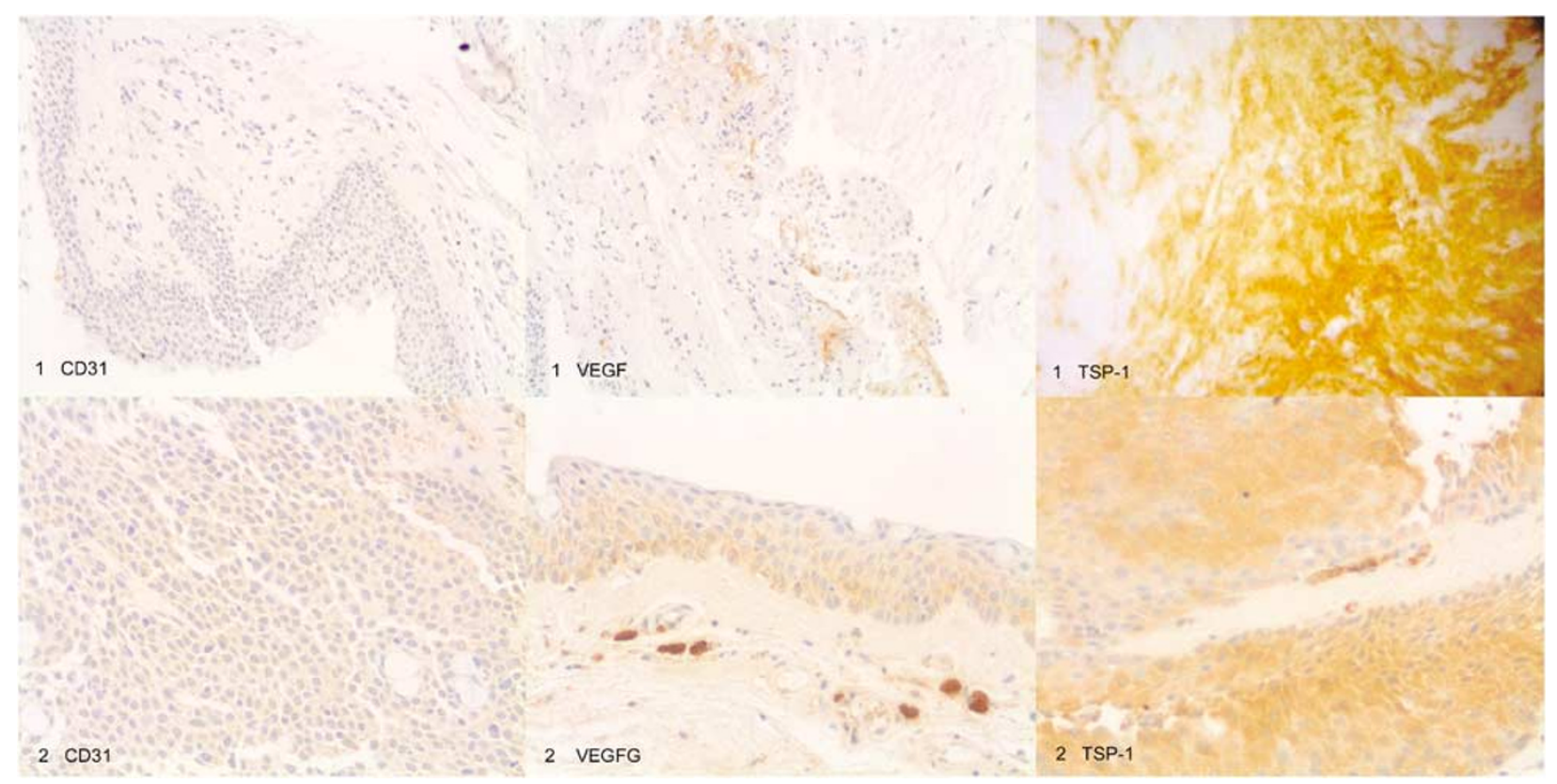

Figure 2 Immunohistochemical analysis of normal conjunctivae (1) and pterygium (2) for CD31, VEGF, and TSP-1 antibodies. Note (a) the presence of relatively small number of subepithelial CD31-positive vessels in conjunctival compared to pterygium tissue, (b) the intense staining of epithelial conjunctival cells for VEGF compared to the mild staining of pterygium, and (c) the absence of TSP-1 stromal expression in conjunctivae compared to the mild, patchy expression in pterygium. 
Table 2 Comparative results of expression levels of proteins CD31, VEGF, and TSP-1 in pterygium and normal conjunctiva

\begin{tabular}{|c|c|c|c|}
\hline & Pterygium & $\begin{array}{c}\text { Normal } \\
\text { conjunctivae }\end{array}$ & P-value \\
\hline CD31-MVD & $17.97 \pm 8.5(\mathrm{SD})$ & $5.72 \pm 5(\mathrm{SD})$ & $P=0.001$ \\
\hline VEGF (\%) & $58.03 \pm 31.23(\mathrm{SD})$ & $83.14 \pm 36.08(\mathrm{SD})$ & $P=0.007$ \\
\hline \multicolumn{4}{|c|}{ VEGF-endothelial } \\
\hline (0) & $15(28.8 \%)$ & $7(100 \%)$ & $P<0.0001$ \\
\hline$(+/++)$ & $37(71.2 \%)$ & 0 & - \\
\hline \multicolumn{4}{|c|}{ VEGF-stromal } \\
\hline (0) & $1(1.9 \%)$ & $7(100 \%)$ & $P<0.0001$ \\
\hline$(+/++)$ & $51(98.1 \%)$ & 0 & - \\
\hline \multicolumn{4}{|l|}{ TSP-1 } \\
\hline 0 & $23(44.2 \%)$ & $4(57.1 \%)$ & $P=0.327$ \\
\hline 1 & $19(36.5 \%)$ & $3(42.9 \%)$ & - \\
\hline 2 & $10(19.3 \%)$ & 0 & - \\
\hline
\end{tabular}

$\mathrm{MVD}=$ microvessel density; $\mathrm{SD}=$ standard deviation; TSP- $1=$ thrombospondin-1; VEGF = vascular endothelial growth factor.

relatively high frequency of intense staining stromal cells as well as vessels covered by VEGF-positive endothelial cells in pterygium tissue $(P<0.0001)$ (Table 2$)$. Finally, MVD pterygium values presented significant correlation with VEGF stromal expression $(P=0.049)$.

In $23 / 52(44.2 \%)$ pterygia, no immunoreactivity for TSP-1 was demonstrated, while no significant correlation was observed compared to normal conjunctivae. Results are shown in Table 2. In Figure 2, an intense case is presented.

In addition, mixed pterygium type presented significantly higher MVD values compared to fibrous ones (17.66 vs 9.56 per high power field, $P=0.026$ ), whereas immunoreactivity for VEGF was higher in pterygium of vascular type $(P=0.048)$.

\section{Discussion}

Pterygium represents vascular, potentially invasive surface ocular lesions, which originate from activated stem cells of the limbus. ${ }^{20}$ Immunopathogenic mechanisms $\mathrm{s}^{21}$ and overexpression of extracellular matrix components ${ }^{22}$ seems to be implicated to their pathogenesis. Furthermore, recent studies show that pterygium can be the result of defective wound healing process, during which molecular events that lead to programmed cell death are modified..$^{23,24}$

In the present study, the overexpression of VEGF in pterygium and the presence of abundant CD31-positive microvessels seems to be in accordance with previous reports ${ }^{25-27}$ that consider neoangiogenesis a potentially important pathogenic contributor of pterygium.
We demonstrated that VEGF is overexpressed in pterygium endothelial and stromal cells, but not in epithelial cells, compared to normal conjunctival tissue. We should emphasize that VEGF has been reported ${ }^{28}$ to be expressed in normal conjunctivae and other ocular tissues with neoangiogenesis. The result of the presented study contradicts previous reports, ${ }^{29-32}$ which demonstrated higher VEGF expression levels in pterygium compared to normal conjunctiva. We must notice that with the exception of the study of Van Setten et $a l^{32}$ and Marcovich et $a l^{29}$ all other studies focus on the overexpression of VEGF in epithelial and vascular endothelial component of pterygium compared to normal conjunctivae. We emphasized in contrast to previous observers that the stromal compartment of pterygium presented a statistically significant higher expression compared to normal tissue. The intense expression of VEGF in epithelial cells of normal conjunctivae is probably not capable of inducing angiogenesis, as it seems to be from the low corresponding MVD values. This phenomenon is probably attributed to the absence of VEGF from endothelial and stromal cells. On the contrary, expression of VEGF in endothelial as well as in stromal cells of pterygium is probably capable of inducing significant angiogenic activity, expressed by high MVD values. We can postulate based on our observations that the accumulation of VEGF in epithelial cells reflects its production, whereas its accumulation in endothelial and stromal cells reflects its angiogenic activity. This is further emerges in our study by the finding of higher MVD values in fibrous compared to vascular pterygium subtypes. We confirm in this way the hypothesis of previous reports that stroma is quite important in pterygium pathogenesis. ${ }^{33}$ According to these reports, the presence of proinflammatory cytokines secreted from the surface epithelium or from tears inflammatory cells induces the fibroblastic production of proteins related to remodelling of extracellular matrix and angiogenesis. Growth factors with potent angiogenic activity, such as FGF, PDGF, TGF- $\beta$, and TNF, have been found ${ }^{6}$ to be secreted from fibroblastic and inflammatory pterygium cells as well as in tissue cultures from pterygium fibroblasts. From this and other studies, ${ }^{34}$ we can postulate that various cytokines and growth factors including VEGF, attribute to cellular proliferation, inflammatory reaction, remodelling of extracellular matrix, and angiogenesis of pterygium.

One important finding of the present study was the characteristic absence of TSP-1, a well-known angiogenesis inhibitor, from almost half $(44.2 \%)$ pterygium cases. The role of TSP-1 in the regulation of angiogenesis is not clear. Positive and negative effects of TSP-1 in angiogenesis have been reported. TSP-1 has 
an antiangiogenic activity that is involved ${ }^{35}$ in the interaction of the microvascular endothelial cell receptor CD36 and in vivo and in vitro studies. In vivo and in vitro studies ${ }^{36-38}$ have been shown that this protein may be inhibitory to angiogenesis. In contrast to these findings, a recent study by Nicosia and Tuszynski ${ }^{39}$ has suggested that matrix-bound TSP-1 may indirectly promote angiogenesis in vitro. Our study is the first that deals with TSP-1 expression levels in pterygium, and in order to understand the results, we should take into consideration the double role of TSP-1 concerning angiogenesis.

Based on the above findings, we conclude that the overexpression of angiogenic factors and the concurrent decreased expression of angiogenesis inhibitor probably supplies one pathway for the pathogenic mechanism of pterygium as well as the possibility for therapeutic intervention in order to avoid pterygium recurrences.

\section{References}

1 Spencer WH. Ophthalmic Pathology: An Atlas and Textbook, 3rd edn. WB Saunders Co: Philadelphia, 1985, pp 304

2 Reese AB. Tumors of the Eye, 3rd edn. Harper \& Row: New York, 1976, pp 53-55.

3 Cameron ME. Histology of pterygium: an electron microscopic study. Br J Ophthalmol 1983; 67: 604-608.

4 Hill JC, Maske R. Pathogenesis of pterygium. Eye 1989; 3: 218-226 (review).

5 Taylor HR, West SK, Rosenthal FS, Munoz B, Newland HS, Emmett EA. Corneal changes associated with chronic UV irradiation. Arch Ophthalmol 1989; 107: 1481-1484.

6 Kria L, Ohira A, Amemiya T. Immunohistochemical localization of basic fibroblast growth factor, platelet derived growth factor, transforming growth factor- $\beta$ and tumor necrosis factor- $\alpha$ in the pterygium. Acta Histochem 1996; 98: 195-201.

7 Cunliffe IA, Richardson PS, Rees RC, Rennie IG. Effect of TNF, IL-1, and IL-6 on the proliferation of human Tenon's capsule fibroblasts in tissue culture. Br J Ophthalmol 1995; 79 : 590-595.

8 Folkman J, Klagsbrun M. Angiogenic factors. Science 1987; 235: 442-447.

9 Tsanou E, Ioachim E, Stefaniotou M, Gorezis S, Charalabopoulos K, Bagli H et al. Immunohistochemical study of angiogenesis and proliferative activity in epiretinal membranes. Int J Clin Pract 2005; 59: 1157-1161.

10 Ferrara N. Vascular endothelial growth factor. Eur J Cancer 1996; 32: 2413-2422.

11 Drovak HF, Brown LF, Detmar M, Dvorak AM. Vascular permeability factor/vascular endothelial growth factor, microvascular hyperpermeability and angiogenesis. Am J Pathol 1995; 146: 1029-1039.

12 Ferrara N, Alitalo K. Clinical application of angiogenic growth factors and their inhibitors. Nat Med 1999; 5: 1359-1364.

13 Nicosia RF. What is the role of vascular endothelial growth factor-related molecules in tumor angiogenesis? Am J Pathol 1998; 153: 11-16.
14 Leung DW, Cachianes G, Kuang WJ, Goeddel DV, Ferrara $\mathrm{N}$. Vascular endothelial growth factor is a secreted angiogenic mitogen. Science 1989; 246: 1306-1309.

15 Senger DR, Galli SJ, Dvorak AM, Perruzzi CA, Harvey VS, Dvorak HF. Tumor cells secrete a vascular permeability factor that promotes accumulation of ascites fluid. Science 1983; 219: 983-985.

16 Dvorak HF. Tumours: wounds that do not heal-similarity between tumour stroma generation and wound healing. N Engl J Med 1983; 315: 1650-1658.

17 Unemori EN, Ferrara N, Bauer EA, Amento E. Vascular endothelial growth factor induces interstitial collagenase expression in human endothelial cells. J Cell Physiol 1992; 153: $557-562$.

18 Roberts DD. Regulation of tumor growth and metastasis by thrombospondin-1. FASEB J 1996; 10: 1183-1191 (review).

19 Taraboletti G, Roberts D, Liotta LA, Giavazzi R. Platelet thrombospondin modulates endothelial cell adhesion, motility, and growth: a potential angiogenesis regulatory factor. J Cell Biol 1990; 111: 765-772.

20 Dushku N, Reid TW. Immunohistochemical evidence that human pterygia originate from an invasion of vimentinexpressing altered limbal epithelial basal cells. Curr Eye Res 1994; 13: 473-481.

21 Karukonda SR, Thompson HW, Beuerman RW, Lam DS, Wilson R, Chew SJ et al. Cell cycle kinetics in pterygium at three latitudes. Br J Ophthalmol 1995; 79: 313-317.

22 Ioachim-Velogianni E, Tsironi E, Agnantis N, Datseris G, Psilas K. HLA-DR antigen expression in pterygium epithelial cells and lymphocyte subpopulations: an immunohistochemistry study. Ger J Ophthalmol 1995; 4: 123-129.

23 Dushku N, Reid TW. P53 expression in altered limbal basal cells of pingueculae, pterygia and limbal tumors. Curr Eye Res 1997; 16: 1179-1192.

24 Tan DT, Tang WY, Liu YP, Goh HS, Smith DR. Apoptosis and apoptosis related gene expression in normal conjunctiva and pterygium. Br J Ophthalmol 2000; 84: 212-216.

25 Di Girolamo N, McCluskey P, Lloyd A, Coroneo MT, Wakefield D. Expression of MMPs and TIMPs in human pterygia and cultured pterygium epithelial cells. Invest Ophthalmol Vis Sci 2000; 41: 671-679.

26 Seifert P, Sekundo W. Capillaries in the epithelium of pterygium. Br J Ophthalmol 1998; 82: 77-81.

27 Lee DH, Cho HJ, Kim JT, Choi JS, Joo CK. Expression of vascular endothelial growth factor and inducible nitric oxide synthase in pterygia. Cornea 2001; 20: 738-742.

28 Kim I, Ryan AM, Rohan R, Amano S, Agular S, Miller JW et al. Constitutive expression of VEGF, VEGFR-1, and VEGFR-2 in normal eyes. Invest Ophthalmol Vis Sci 1999; 40: 2115-2121.

29 Marcovich AL, Morad Y, Sandbank J, Huszar M, Rosner M, Pollack A et al. Angiogenesis in pterygium: morphometric and immunohistochemical study. Curr Eye Res 2002; 25: $17-22$.

30 Gebhardt M, Mentlein R, Schaudig U, Pufe T, Recker K, Nölle B et al. Differential expression of vascular endothelial growth factor implies the limbal origin of pterygia. Ophthalmology 2005; 112: 1023-1030.

31 Jin J, Guan M, Sima J, Gao G, Zhang M, Liu Z et al. Decreased pigment epithelium-derived factor and increased vascular endothelial growth factor levels in pterygia. Cornea 2003; 22: 473-477. 
32 Van Setten G, Aspiotis M, Blalock T, Grotemdorst G, Schultz G. Connective tissue growth factor in pterygium: simultaneous presence of vascular endothelial growth factorpossible contributing factor to conjunctival scarring. Graefe's Arch Clin Exp Ophthalmol 2003; 241: 135-139.

33 Solomon A, Li DQ, Lee SB, Tseng SC. Regulation of collagenase, stromelysin, and urokinase-type plasminogen activator in primary pterygium body fibroblasts by inflammatory cytokines. Invest Ophthalmol Vis Sci 2000; 41: 2154-2163.

34 Roberts AB, Sporn MB. Growth factors and transformation. Cancer Surv 1986; 5: 405-412.

35 Jimenez B, Volpert OV, Crawford SE, Febbraio M, Silverstein RL, Bouck N. Signals leading to apoptosis-dependent inhibition of neovascularization by thrombospondin-1. Nat Med 2000; 6: 41-48.
36 Iruela-Arispe ML, Bornstein P, Sage H. Thrombospondin exerts an antiangiogenic effect on cord formation by endothelial cells in vitro. Proc Natl Acad Sci USA 1991; 88: 5026-5030.

37 Good DJ, Polverini PJ, Rastinejad F, Le Beau MM, Lemons RS, Frazier WA et al. A tumor suppressor-dependent inhibitor of angiogenesis is immunologically and functionally indistinguishable from a fragment of thrombospondin. Proc Natl Acad Sci USA 1990; 87: 6624-6628.

38 Tolsma SS, Volpert OV, Good DJ, Frazier WA, Polverini PJ, Bouck N. Peptides derived from two separate domains of the matrix protein thrombospondin- 1 have anti-angiogenic activity. J Cell Biol 1993; 122: 497-511.

39 Nicosia RF, Tuszynski GP. Matrix-bound thrombospondin promotes angiogenesis in vitro. J Cell Biol 1994; 124: 183-193. 